\title{
Implementation of Quality Assurance Standards and Principals' Administrative Effectiveness in Public Secondary Schools in Edo and Delta States
}

\author{
U. Momoh ${ }^{1, *} \&$ Emmanuel Osamiro Osagiobare ${ }^{2}$ \\ ${ }^{1}$ Department of Educational Management, Faculty of Education, University of Benin, Benin City, Nigeria \\ ${ }^{2}$ Department of Educational Foundation, Faculty of Education, University of Benin, Benin City, Nigeria \\ *Correspondence: Department of Educational Studies and Management, Faculty of Education, University Of Benin, \\ Benin City, Nigeria. Tel: 234-805-348-1970. E-mail: Drumomoh@Gmail.Com
}

Received: May 7, 2015

doi:10.5430/wje.v5n3p107
Accepted: May 26, 2015 Online Published: June 8, 2015

URL: http://dx.doi.org/10.5430/wje.v5n3p107

\begin{abstract}
The study investigated principals' implementation of quality assurance standards and administrative effectiveness in public secondary schools in Edo and Delta States. To guide the study, four research questions and hypotheses were raised. Descriptive research design was adopted for the study and the simple random sampling technique was used to select 240 principals and 720 teachers used for the study. Two set of instrument were used to collect data which was analysed using the Mean, Percentage, Pearson's Product Moment Correlation (r), Zero Differentiation Hypothesis and Fisher z statistical tools. The findings revealed that though not all quality assurance standards in Edo and Delta public secondary schools were implemented, the level of principals' administrative effectiveness is high and experience significantly contributed to their performance. It was thus recommended that, principals be empowered to implement quality assurance standards and experience should be major criteria for appointing principals so that quality assurance standards can be effectively implemented.
\end{abstract}

Keywords: implementation; quality assurance standards and administrative effectiveness

\section{Introduction}

Education is an imperative instrument and a basic force used for determining the development of any nation (Imogie, 2014). It entails the totality of all skills, competences, attitudes and values which an individual acquires over time for survival and development of the society. It can therefore be deduced that the goal, orientation, quality and content of the educational system opted for by any country is a crucial determinant of the direction of its national development and the pace of such development. Consequently, the priority of education policy of government in Nigeria at all levels is to ensure equitable access and improvement in quality and efficiency. This is guided by the principle that good education can contribute significantly to economic growth and income generating opportunities for sustainable development. The desire 'to ensure quality control through regular and continuous supervision of instructional and other educational services' (FRN, 2004:56), led to the institutionalization of a viable quality assurance approach that would be functional and be able to meet global standards. This can be achieved through effective supervision involving internal and external assessment of performance using the same instrument to ensure excellence It therefore means that there is a standard set and a process put in place to verify and determine whether products or services meet or exceed customer expectation, customer in this context being students; this is the kernel of quality assurance.

The Principal as an administrative leader and implementer of education policies in the secondary school must continually strive to satisfy recipients of the system to ensure that quality is attained in all its' ramification. He is saddled with the responsibility of providing leadership that will enhance quality teaching and learning which is geared towards the actualization of organizational goals and having an effective school. An effective school administrator is an even greater asset since he deals with young people on the one hand and adults on the other, thus providing an effective seamless link between the school community and individuals which ultimately determines the 
administrator's success. Consequently, the crux of this study is to look beyond pedagogy to examine administrative processes for effective quality delivery in accordance with set standard.

\section{Literature Review}

Quality assurance provides for an all inclusive education involving all stakeholders in decision-making including students who are empowered to take responsibility for their own learning. It is the concern of the Inspectorate Service of the Federal Ministry of Education (FME) charged with the responsibility of ensuring that standards are maintained in learning activities. Decree No. 16 (Now Act 16) of 1985 contains the guidelines on minimum standard in Nigeria schools. Assessing school effectiveness in the light of the ongoing becomes a complex and multifaceted phenomenon as it depends on a lot of variables. However, the work of Blanchard (1997) affirmed that principals' administrative effectiveness is a function of situational variables on the job, position power, leader-member relationship and knowledge. This conclusion was drawn using Fieldler's contingency model which correlated leadership style with the measure of effectiveness. The model draws a relationship between the attributes of a leader and the environment; leaders would behave differently when faced with the same situation depending on their abilities. Based on Fieldlers' theory, Blanchard suggested that for effectiveness to be increased, the principal must increase situational control, meaning that leader-member relations should be improved, and that knowledge and experience on the job and position power, be expanded. Ibukun, Oyewole and Abe (2011) thus concluded that on the basis of Fieldler's theory on school administration it is imperative to motivate teachers and students in a concerted effort at creating an effective school. An effective school is that where the principal is able to implement quality assurance standards by functioning in the following ways:

- Has a pervasive and broadly understood focus on teaching and learning;

- Has a safe and orderly school learning climate that is conducive to teaching;

- Has high expectations for achievement from all students;

- Ensures parental involvement in homework;

- Uses student achievement test data to evaluate programmes and school successes

- There is Pupil involvement in school activities

- Has a strong leadership;

Ogunu (2007) describes quality assurance as the management of goods, services and activities from the input stage through processes to the output stage of production with the aim of preventing quality problems and ensuring that only conforming products reach the customer. Corroborating this description is Arikewuyo (2004) who sees quality assurance in education as its ability to enable students to perform well in standard examinations and relevance to the needs of the students, community, and the society as a whole. The dimensions of quality assurance in education as spelt out in the FRN Quality Assurance Handbook (2010) are: Infrastructure and Physical standard, Curriculum and content standard, Teaching and learning standard, Management and leadership standard, Care, guidance and support standards and Professional standard. It is the responsibility of the principal as the head of administration to implement these standards in line with the benchmarks. However, the principal is confronted with an often overwhelming myriad of responsibilities, demands, pressures and expectations. He is expected to fill many roles; set the tone and pace of the school, see the school program run smoothly and efficiently. A study carried out by Humphreys, Jiao and Saddler (2008) on competencies of Rural Oklahoma school principals, revealed that both the principals and the teachers felt that principals should possess competencies in community relation and service, pupil personnel services, pupil control and personnel services. The findings suggested that both groups view Principal-ship as a position in which competencies in dealing with the human component of the school (community, teachers, students and central office personnel) and with the improvement of the educational program are ideally important.

Studies carried out on administrative effectiveness of principals on the basis of sex by Omoike and Idogho (2011) revealed that there was no significant difference in male and female heads of departments. Similarly, Hemphill, Griffiths and Fredrickson (1992) found in their study of 'Administrative Performance and Personality' in New York that male principals didn't demonstrate superior performance than their female counterparts. Barter (2001) in a survey of group of teachers rated male and female principals as equal in ability and personal qualities. Though Ibrahim and Al-Tanaji (2012) in a study they carried out in Dubai schools on principals' leadership style and school performance found out that principals' level of effectiveness differed according to gender; female principals were more effective than their male counterparts, that schools with female principals had better performance than schools 
with male principals. Grobaman and Hiries (1996) in a study of what makes a good principal, also noted that men ranked significantly ahead of women as democratic leaders.

Blanchard (1997) revealed from the findings in a study of leadership effectiveness of Wisconsin elementary schools that experience constitutes another major factor in principals' effectiveness. He concluded that some schools experience more conflicts than others due to the principals' level of leadership effectiveness as a result of experience on the job. Rapid expansion through the creation of junior and senior secondary schools in Nigeria means that more teachers may be recruited as principals and some of whom may have less experience. Okolo (2007) in a study carried out on the performance of primary school headmasters in Nigeria discovered that there was a significant difference in the performance between primary school head teachers with 4-11years experience and those with 20 years and above. Studies carried out by Rice (2010) shows that the principals' job is multi faceted, and the effectiveness of Principal depends on their level of experience, their sense of efficacy of particular kinds of tasks, and their allocation of time across daily responsibilities. Findings from the work also demonstrate that principals with experience and skills are found to be more effective. It can thus be inferred that experience significantly contribute to their performance.

A study on the evaluation of secondary school principals carried out by Eyike (2001) revealed that principals who are professionally trained performed their roles better than non-professionals. This supports Amanchi (1998) who reported that teachers who complete degrees in education are more professional in outputs than those who do not. It is believed that specialized training empowers and motivates such teachers for better performance while preparing them for higher responsibilities.

\section{Research Problem}

Stakeholders; parents and government have been worried and concerned over the need to ensure improvement in the quality of the education system and thus the focus on school administration which is saddled with the responsibility of providing leadership. This is against the backdrop that benchmarks for standards have been set and it is the role of school principals to implement these standards in the schools. It however appears that secondary schools are faced with poor administrative leadership that will enhance quality teaching and learning which are geared towards the actualization of organizational goals. This study therefore attempts to assess the implementation of quality assurance standards and administrative effectiveness of principals in public secondary schools in Edo and Delta States as case study.

\section{Research Questions}

1) What percentage of quality assurance standards is implemented in public secondary schools in Edo and Delta states?

2) What is the level of principals' administrative effectiveness in public secondary schools in Edo and Delta States?

3) Is there a relationship between the implementation of quality assurance standards and administrative effectiveness by sex of principals in public secondary schools in Edo and Delta States?

4) Is there a relationship between the implementation of quality assurance standards and administrative effectiveness based on years of experience of principals in public secondary schools in Edo and Delta States?

5) Is there a relationship between the implementation of quality assurance standards and administrative effectiveness based on qualification of principals in public secondary schools in Edo and Delta States?

Research question one will be answered using a graph while questions 2-5 will be hypothesised as follows:

\section{Hypotheses}

Ho1: Principals' administrative effectiveness will not be high in public secondary schools in Edo and Delta states.

Ho2: There is no significant relationship between the implementation of quality assurance standards and administrative effectiveness by sex of principals in public secondary schools in Edo and Delta States.

Ho3: There is no significant relationship between the implementation of quality assurance standards and principals' administrative effectiveness based on years of experience of principals in public secondary schools in Edo and Delta States. 
Ho4: There is no significant relationship between the implementation of quality assurance standards and principals' administrative effectiveness based on years of qualification of principals in public secondary schools in Edo and Delta States.

\section{Methodology}

The study adopted the descriptive research design with a population of all the principals and teachers in Edo and Delta State public secondary schools; the simple random sampling technique was used to select 240 principals and 720 teachers who were used to study the principals. Data was collected using 'Implementation of Quality Assurance Standard Checklist (IQASC)' and 'Principals' Administrative Effectiveness Questionnaire (PAEQ)'. Data collected were analysed using Percentage, Standard Deviation and Zero Differentiation Hypothesis. Pearson's Product Moment Correlation Coefficient was used to test the hypotheses raised and Fisher z statistical tools because of the extra variables raised in the study.

\section{Discussion of Result}

The concern of this study was to assess the implementation of quality assurance standards and principals' administrative effectiveness in public secondary schools in Edo and Delta States. The findings revealed that only $48 \%$ of the approved standards were implemented in public secondary schools in Edo State and 52\% in Delta State (This is graphically presented in figure 1 of the Appendix). It therefore means that minimum standards as approved by government (Federal Republic of Nigeria, 1985) for Secondary Schools are not fully implemented in Edo and Delta States.

The study also revealed that the level of principals' administrative effectiveness was high in the Secondary Schools in the States (See Table1 in appendix). Sex and qualification of principals were however found not to be significant factors (See Table 2\&3) which aligns with the findings in the study of Hamphill, Griffiths and Fredrikson (1992) and Omoike and Idogho (2011) in their studies found that, men did not demonstrate superior performance neither are they superior to women in Principalship. Though Wiles, Grobaman and Hiries (1996), Adigwu (2004) and Ibraham and Al-Taneiji (2012) have a contrary opinion as they assert that men ranked significantly ahead of women as leaders and that principals level of effectiveness differed according to gender. What seem to be of importance in this study is experience as revealed in the result of significant relationship between experienced and inexperienced principals in this study (See Table 4\&5). This is supported by the studies and findings of Adesina (1990), Schein (1997), Okolo (2007) and Rice (2010) who all agree that experience significantly contribute to principals' performance. Besides in Edo and Delta state, teachers must have attained level 14 or a minimum of 8-10 years as a classroom teacher before attaining the position of a principal thus ensuring that they have acquired enough experience to face the challenges of administration. This however did not underscore the importance of qualification that was found significant in this study (See tables 6\&7) thus supporting Amanchi (1998) and Eyike (2001)'s findings that principals who are professionally trained with an NCE or degree in education performed their roles better than non-professionals.

\section{Conclusion}

This study revealed that not all quality assurance standards are implemented in Edo and Delta States public secondary schools though the level of administrative effectiveness of principals is high. A further investigation showed that while sex and qualification of principals were important, the most significant factor in principals' implementation of quality assurance standards and administrative effectiveness is experience.

\section{Implications of the Findings to Educational Administration}

Since principals' administrative effectiveness in Edo and Delta states public secondary schools was found to be high, they should be supported to implement all the quality assurance standards and experienced teachers with the prerequisite administrative skills should be made principals irrespective of their qualification and sex.

\section{Recommendations}

Government should support the efforts of the principals through adequate funding and manpower requirement so that they will be empowered to implement quality assurance standards in line with the benchmarks. 
Sex and qualification of principal should not be the yardstick for appointment; experience should be the key criteria.

\section{References}

Amanchi, D. (1998). Accountability in Nigeria states: towards a posture for better education. Journal of Nigerian Educational Research Association, 1(2), 85-91.

Arikewuyo, M. O. (2004). Effective funding and quality assurance in the Nigerian education system. Paper presented at the $1^{\text {st }}$ National Conference of the Institute of Education, Olabisi Onabanjo University, Ago-Iwoye. January. pp 12-15.

Barter, A. L. (2001). The status of women in school administration. Educational Horizons, Spring.

Blanchard, L. L. (1997). The leadership effectiveness of wisconsin elementary school. Principals' Dissertation Abstracts international, 39(6).

Eyike, R.E. (2001). An evaluation of secondary school Principals in Edo State. (M.Ed. Thesis) University of Benin, Nigeria.

Federal Inspectorate Service (FIS), (2009). Quality assurance Handbook for Basic and Secondary Education in Nigeria. Edited by Oyinloye, E.M., Ochuba, V. O. and Azubuike, C. U. Nigeria

FRN, (1985). Guidelines on minimum standard in Nigerian schools. (The Education National Minimum Standard Establishment Institutions Decree No. 16 of 1985).

FRN, (2004). National policy on Education ( $4^{\text {th }}$ ed.). Lagos, NERDC press 4, 39.

Hemphil, K., Griffiths, D. E., \& Fredrickson, N. (1992). Administrative performance and personality. New York Bureau of Publication, University of Columbia.

Ibrahim, A. S., \& Al-Tanaji, S. (2012). Principals' leadership style, School performance and principals effectiveness in Dubai schools. International Journal of Research Studies in Education, 2(1), 41-54

Ibukun, W. O., Oyewole, B. K., \& Abe, T. O. (2011). Personality characteristics and principal leadership effectiveness in Ekiti State. Nigeria International Journal of Leadership studies, 6(2).

Nwagwu, N.A., Ijeoma, M.A., \& Nwagwu, C.C. (2004). Organization and administration of education: Perspective and Practices. University of Benin, Benin City.

Ogunu, M.A. (2007). The role of supervision in quality assurance. Paper presented at the Training Workshop for Inspectors of Education and Education Officers in Edo State at Bishop Kelly Pastoral Centre, Benin City.

Oloko, O. M. (2013). Quality education and content curriculum. A paper presented at the $13^{\text {th }}$ FOMWAN National Education summit. Ogun State, June 2013.

Omoike, D., \& Idogho, O. A. (2008). Gender disparity in administrative effectiveness of head of academic departments in Nigerian Universities. Department of Education Foundations and Management, Ambrose Alli University Ekpoma. Edo state Nigeria.

Rice, J. K. (2010). Principal's effectiveness and leadership in an era of accountability: what research says. Centre for analysis of longitudinal data in Education research.

2010 November/December WAEC (wasscegce.examination.html) results

\section{Appendices}

\section{Research Question One}

1. What percentage of quality assurance standards is implemented in public secondary schools in Edo and Delta states?

To answer research question one, a checklist containing the benchmark for quality assurance standards approved by the Inspectorate Division of the Federal Ministry of Education was used. The result is presented graphically here using percentages: 


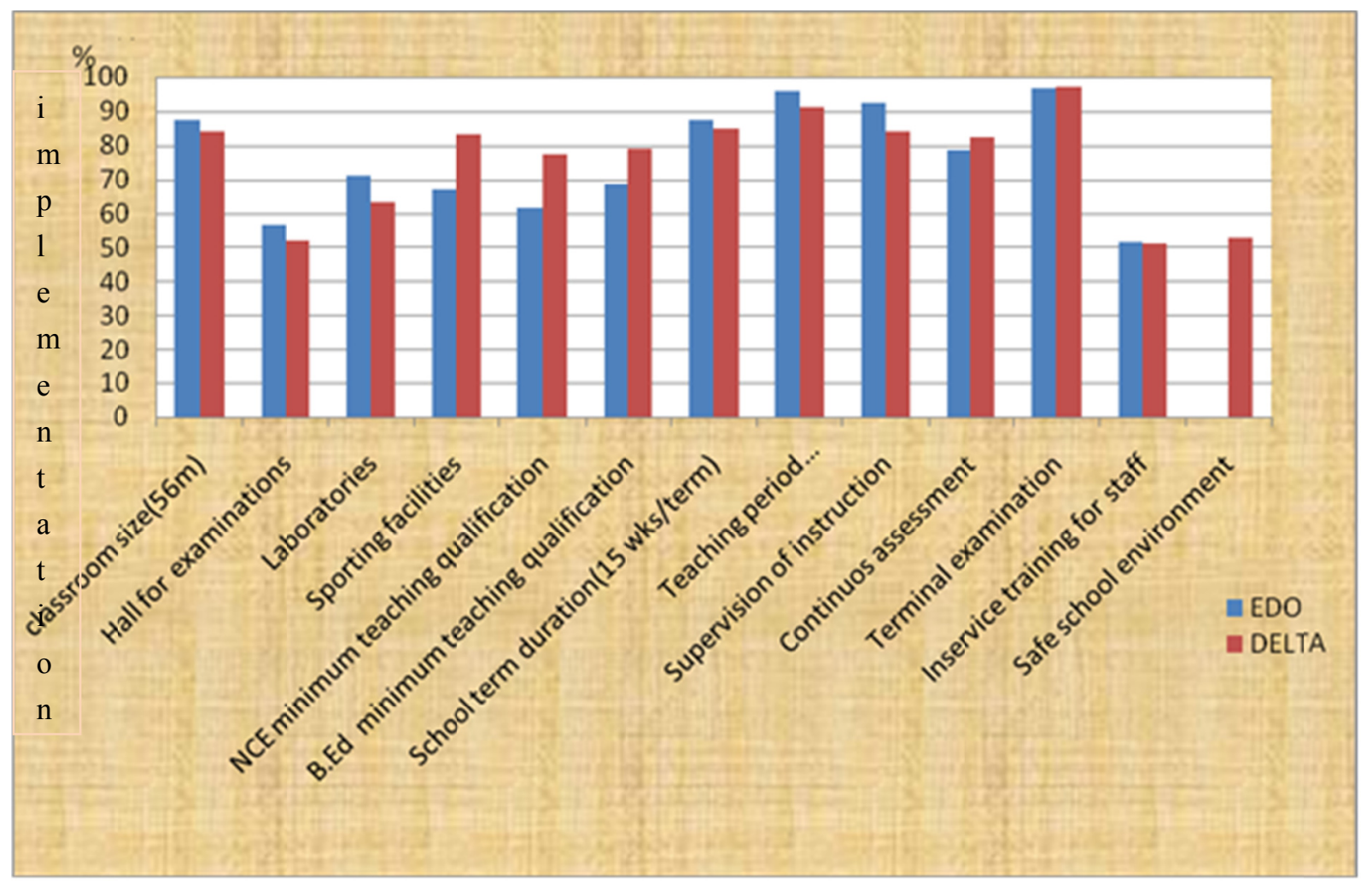

Figure 1. Graphical presentation of Quality Assurance Standards Implemented in Public Secondary Schools in Edo and Delta States

\section{Hypothesis one}

Principals' administrative effectiveness will not be high in public secondary schools in Edo and Delta states

Table 1. Principals Administrative Effectiveness in Public Secondary Schools in Edo and Delta States

\begin{tabular}{|c|c|c|c|c|c|c|c|}
\hline $\mathrm{N}$ & Weighted & $\bar{X}$ & Diff & SD & Calculated Z & Critical Z & Remark \\
\hline & Calculated & 63.52 & & & & & \\
\hline 720 & Normative & 62.5 & 719 & 17.86 & 2.20 & 1.96 & Significant \\
\hline
\end{tabular}

The data in table 1 shows the calculated mean of principals' administrative effectiveness is 63.52 and the normative mean is 62.5 . The result of the analysis is significant since the calculated $\mathrm{Z}$ of 2.20 is greater than the critical $\mathrm{Z}$ of \pm 1.96 and less than the normative mean of 62.5. It therefore implies that the hypothesis that principals' administrative effectiveness in public secondary schools in Edo and Delta states will not be high is rejected.

\section{Hypothesis two}

There is no significant relationship between the implementation of quality assurance standards and administrative effectiveness by sex of principals in public secondary schools in Edo and Delta States.

Table 2. Implementation of Quality Assurance Standards and Administrative Effectiveness by Sex

\begin{tabular}{clc}
\hline Principals' sex & & Principals' Effectiveness \\
\hline Male & Principals' Effectiveness & 1 \\
$\mathbf{( N = 3 1 5 )}$ & Quality Assurance Standards & $.258^{*}$ \\
Female & Principals' Effectiveness & 1 \\
$(\mathbf{N}=\mathbf{4 0 5})$ & Quality Assurance Standards & $.315^{*}$ \\
\hline
\end{tabular}

*Significant at $\mathbf{P}=<0.05$

Table 2 shows a significant and positive relationship between the variables for male and female Principals. However, the degree of relationship is higher among the female principals. Fisher $\mathrm{Z}$ test was thus carried out to ascertain if this difference is significant. This is presented in the table 3 . 
Table 3. Fisher Z Analysis for Male and Female Principals

\begin{tabular}{|c|c|c|c|c|c|c|}
\hline Principals' sex & $\mathbf{N}$ & Pearson & $\mathbf{r}$ & $\begin{array}{l}\text { Z-score } \\
\text { Observed }\end{array}$ & Z-score Critical & Decision \\
\hline Male & 315 & .258 & & & & \\
\hline Female & 405 & .315 & & -2.03 & \pm 1.96 & Not Significant \\
\hline
\end{tabular}

From the data in Table 3, there is a small strength of correlation of Pearson $r$ value of .258 between the variables for the male principals and a moderate strength of correlation Pearson $r$ value of .315 for the female Principals. Since there were two groups, the Pearson $r$ correlations of the two categories of gender were transformed to Z-scores for testing of the hypothesis. The result indicates that the Z-score is not significant because 1.96 is greater than $\mathrm{Z}$ observed of -2.03 and less than \pm 1.96 . The hypothesis that there is no significant relationship between principals' implementation of quality assurance standards and administrative effectiveness by gender is therefore retained.

\section{Hypothesis three}

There is no significant relationship between the implementation of quality assurance standards and principals' administrative effectiveness based on years of experience of principals in public secondary schools in Edo and Delta States.

Table 4. Implementation of Quality Assurance Standards and Administrative Effectiveness based on Experience

\begin{tabular}{clc}
\hline Principals' Experience & Principals' Effectiveness \\
\hline & & \\
$\mathbf{0 - 1 0 Y e a r s}$ & Principals' Effectiveness & 1 \\
$(\mathbf{N}=\mathbf{3 1 2})$ & Quality Assurance Standards & $.366^{*}$ \\
Above 10Years & Principals' Effectiveness & 1 \\
$(\mathbf{N}=\mathbf{4 0 8})$ & Quality Assurance Standards & $.225^{*}$ \\
\hline
\end{tabular}

*Significant at $\mathbf{P}=<\mathbf{0 . 0 5}$

Table 4 shows that there is a significant and positive relationship between the variables among inexperienced and experienced principals. From the analysis, the degree of relationship was found to be higher among experienced principals than inexperienced principals, Fisher $\mathrm{Z}$ test was therefore carried out to find out if this difference is significant. This is presented in table 5 .

Table 5. Fisher Z Analysis for Inexperienced and Experienced Principals

\begin{tabular}{llllll}
\hline $\begin{array}{l}\text { Principals' Years } \\
\text { of Experience }\end{array}$ & N & Pearson & Z-score Observed & Z-score Critical & Decision \\
\hline $\begin{array}{l}\text { 0-10Years } \\
\text { Above 10Years }\end{array}$ & 312 & .366 & 2.17 & \pm 1.96 & Significant \\
\hline
\end{tabular}

Table 5 indicates that there is a moderate strength of correlation of Pearson $r$ value of 366 between principals with 0 -10years and administrative effectiveness. The data also showed a low strength of Pearson $r$ correlation of .225 between principals with over 10years experience and administrative effectiveness. The Pearson $r$ correlation of the two categories of experiences was transformed to Z-scores for testing of the hypothesis since they were two groups. The result indicates a significant relationship because 1.96 is less than $Z$ observed of 2.17 and greater than \pm 1.96 . The null hypothesis that there is no significant relationship between implementation of quality assurance standard and administrative effectiveness based on Principals' experience is therefore rejected.

\section{Hypothesis four}

Table 6. Implementation of Quality Assurance Standards and Administrative Effectiveness by Qualification

\begin{tabular}{clc}
\hline \multicolumn{2}{c}{ Principals' Qualification } & Principals' Effectiveness \\
\hline Professional & Principals' Effectiveness & 1 \\
$(\mathbf{N}=\mathbf{6 4 0})$ & Quality Assurance Standards & $.304 *$ \\
Non Professional & Principals' Effectiveness & 1 \\
$(\mathbf{N}=\mathbf{8 0})$ & Quality Assurance Standards & $.176^{*}$ \\
\hline
\end{tabular}

*Significant at $\mathbf{P}=<\mathbf{0 . 0 5}$ 
Table 6 shows a significant and positive relationship between the variables of study among professional and non professional Principals, though the degree of relationship is higher among professional than non professional Principals. Fisher $Z$ test was carried out to find out if this difference is significant. This is presented in table 7.

Table 7. Summary of Fisher Z Analysis for Professional and Non Professional Principals

\begin{tabular}{llllll}
\hline $\begin{array}{l}\text { Principals' } \\
\text { Qualification }\end{array}$ & N & Pearson $\mathbf{r}$ & $\begin{array}{l}\text { Z-score } \\
\text { Observed }\end{array}$ & $\begin{array}{l}\text { Z-score } \\
\text { Critical }\end{array}$ & Decision \\
\hline $\begin{array}{l}\text { Professional } \\
\text { Non Professional }\end{array}$ & 640 & .304 & 1.13 & \pm 1.96 & Not Significant \\
\hline
\end{tabular}

The data in table 5 reveals that there is a moderate strength of correlation of Pearson $r$ value of .304 between implementation of quality assurance standards and administrative effectiveness among professional principals and a low strength of correlation of Pearson $r$ value of .176 among the nonprofessional principals. The Pearson $r$ correlation of the two groups was transformed to Z-scores for testing of the hypothesis. The result shows that the $\mathrm{Z}$-score is not significant because 1.96 is greater than $\mathrm{Z}$ observed of 1.13 and less than \pm 1.96 . The hypothesis that there is no significant relationship between implementation of quality assurance standards and administrative effectiveness based on principals' qualification is therefore retained. 